LUKASZ KWADRANS

EDUKACJA MIĘDZYKULTUROWA

2017, nr 1 (6)

ISSN 2299-4106

Ewa Sowa-Behtane

MAgdalena URLiŃSKA

\title{
„Młodzi. Przeciw czemu się buntują? Czego pragną? Co budują?” Kraków, 9-10 czerwca 2016 roku
}

Kategoria „młodych”, „młodzieży” od lat jest w zainteresowaniu przedstawicieli nauk społecznych, w tym pedagogiki. Poczynając od sporów definicyjnych, dotyczących chociażby cenzusu czasowego dla określenia tej grupy osób, po współczesne problemy, wyzwania, postawy młodych itp. tematyka młodzieży wydaje się na tyle ważna, aby prowadzić dyskurs naukowy, prowokować badania, dzielić się ich wynikami. Stąd pomysł zorganizowania konferencji w dniach 9-10 czerwca 2016 roku w Krakowie, z inicjatywy pracowników Katedry Pedagogiki Społecznej Wydziału Pedagogicznego Akademii Ignatianum. Zaproponowano współorganizację zaprzyjaźnionym jednostkom akademickim w Polsce, a były to: Zakład Pedagogiki Ogólnej i Metodologii Badań Wydziału Etnologii i Nauk o Edukacji Uniwersytetu Śląskiego w Katowicach oraz Katedra Socjologii Edukacji i Pedagogiki Społecznej Wydziału Nauk Pedagogicznych Uniwersytetu Mikołaja Kopernika w Toruniu. Do rozpropagowania w środowisku naukowym krakowskiej debaty włączyło się Stowarzyszenie Wspierania Edukacji Międzykulturowej. Wobec tego, że konferencja miała charakter międzynarodowy, współorganizatorami były współpracujące z Akademią Ignatianum i partnerami uczelnie zagraniczne: Wydział Edukacji, Językoznawstwa i Sztuki Akademii Technologicznej w Rezekne (Łotwa), Wydział Pedagogiczny Uniwersytetu im. Borysa Grinczenki w Kijowie (Ukraina) oraz Wydział Pedagogiczny Państwowego Uniwersytetu im. Iwana Franki w Żytomierzu (Ukraina). Z tych jednostek przybyły delegacje pracowników i doktorantów, którzy prezentowali wyniki prowadzonych badań.

Patronat nad tym naukowym przedsięwzięciem objęli Jego Magnificencja Rektor Akademii Ignatianum oraz Wojewoda Małopolski, Prezydent Krakowa, Przewodniczący Rady Miasta Krakowa. Swój patronat zapewniły także Zarząd Główny Polskiego Towarzystwa Pedagogicznego oraz Zespół Peda- 
gogiki Kultury i Edukacji Międzykulturowej Komitetu Nauk Pedagogicznych Polskiej Akademii Nauk. Przewodnictwo Komitetów Naukowego i Programowego objęły prof. UMK dr hab. Maria Marta Urlińska oraz prof. UŚ dr hab. Ewa Ogrodzka-Mazur, natomiast kierowanie Komitetem Organizacyjnym przyjęła na siebie dr hab. Joanna Łukasik. Sekretarzami Konferencji zostali: dr Ewa Sowa-Behtane, ks. dr Bogdan Stańkowski oraz doktorantki AIK, mgr Agata Tatara i mgr Magdalena Urlińska.

Pomysł zorganizowania konferencji w Krakowie na taki właśnie temat nie był przypadkowy. Miasto od dwóch lat przygotowywało się do Światowych Dni Młodzieży. To między innymi dlatego, przed tak ważnym wydarzeniem, w oczekiwaniu na przyjęcie młodzieży z całego świata, środowisko akademickie Akademii Ignatianum wsparte przez władze samorządowe województwa i miasta, postanowiło przeprowadzić debatę nad kondycją młodego pokolenia. Zaproszono do udziału w niej badaczy zainteresowanych problematyką młodzieży. Uczestników konferencji przywitała przewodnicząca Komitetu Programowego prof. UMK dr hab. Maria Marta Urlińska a następnie głos zabrali przedstawiciele władz województwa, miasta i uczelni: wicewojewoda małopolski Piotr Ćwik, przewodniczący Rady Miasta Krakowa Bogusław Kośmider, rektor Akademii Ignatianum prof. dr hab. Józef Bremer, SJ oraz dziekan Wydziału Pedagogicznego Akademii Ignatianum dr Krzysztof Biel, SJ. W tej części wspomniano znamienny cytat z wypowiedzi Marszałka Józefa Piłsudskiego: „Kto nie był buntownikiem za młodu, ten będzie świnią na starość".

Wszystkie wystąpienia przygotowane na konferencję zogniskowano w dwóch sesjach plenarnych i sześciu sekcjach problemowych. Pierwsza z sesji plenarnych koncentrowała się wokół tematu: Młodzież w okresie zmian cywilizacyjnych $i$ kulturowych, a moderatorami były: dr hab. Anna Szafrańska (UŚ) oraz dr hab. Joanna Łukasik (AIK). Prof. OSW dr hab. Danuta Wajsprych wystąpieniem pt. Globalizacja - imperializm kulturowy czy nowy indywidualizm wprowadziła uczestników debaty w przestrzeń zmian dokonujących się w świecie współczesnym, po czym prof. dr hab. Olga Suchomlyńska zadała pytanie: Jak wychowywać wspótczesna młodzież - przyktad Ukrainy, po niej prof. dr hab. Liudmyla Khoruzha przedstawiła badania własne na temat Wartości ukraińskich studentów. Prof. zw. dr hab. Andrzej Bałandynowicz w referacie Cyberprzestrzeń jako facylitacja degeneratywnych zachowań młodzieży wskazał na niebezpieczeństwa związane z korzystaniem z Internetu, natomiast prof. UJK dr hab. Anna Kierzkowska, prezentując tekst Immoralna treść przyjaźni i tolerancji w procesie wtórnej socjalizacji, wska- 
zała na rolę wartości w procesie wychowania. Z kolei dr Błażej Przybylski podjął próbę odpowiedzi na pytanie o bunt młodych. W referacie Młodzi zaangażowani czy młodzi obojętni? pokazał wyniki prowadzonych przez siebie eksploracji.

W pierwszym dniu konferencji pracowały trzy sekcje, zatytułowane: $K u$ jakiej tożsamości? Dylematy tożsamościowe wspótczesnej młodzieży (moderatorzy: prof. OSW dr hab. Danuta Wajsprych, dr Markus Lipowicz), Wartości cenione przez młodzież - „przesuwanie się horyzontu aksjologicznego” czy kryzys $w$ wartościowaniu? (moderatorzy: prof. AIK dr hab. Klaudia Węc, prof. dr hab. Olga Sukhomlynska - Ukraińska Akademia Nauk Pedagogicznych), Kryzys kultury a zachowania ryzykowne mtodzieży (moderatorzy: prof. UKJ dr hab. Anna Kieszkowska, dr Krzysztof Biel, SJ). Uczestnicy mieli możliwość wysłuchania 21 wystąpień oraz włączenia się do dyskusji na tematy zasygnalizowane przez prelegentów. Zadawano więc pytania o to: Kim sq młodzi? Kim nie sa? Kim chcieliby być? Jaka jest tożsamość wspótczesnej młodzieży w ujęciu teoretyczno-empirycznym, jak kształtuje się nowoczesna tożsamość młodzieży w kontekście kultur: popularnej, konsumpcyjnej i indywidualizmu; pytano, czy osobowość narcystyczna to znak naszych czasów?

Wskazywano na drogę do skrystalizowanej osobowości w dobie popkultury oraz dialog międzygeneracyjny jako wartość w kształtowaniu tożsamości współczesnego nastolatka. Mówiono o globalizacji i młodości jako wyzwaniu dla współczesnego świata, dyskutowano nad światem wartości młodzieży, wpływem wartości na wychowanie młodzieży, wskazywano na wagę przygotowania nauczycieli do pracy z młodzieżą, na rozwój kompetencji intrapersonalnych, na zjawisko ulubieńców nauczycieli czy też tolerancję nauczycieli dla odmienności obecnej w szkole. Wskazywano też na ruchy kontestacyjne lat 50. i 60. XX wieku jako na zjawiska determinujące postrzeganie zachowań ryzykownych dzieci i młodzieży XXI wieku. Zaprezentowano w ramach tych sekcji działania profilaktyczno-edukacyjne partyworkerów dotyczące ryzykownych zachowań młodzieży oraz resocjalizację nieletnich niedostosowanych społecznie w salezjańskich MOW. Ciekawe były wątki prezentujące subkulturowe grupy młodzieżowe na przestrzeni lat, ważne były egzemplifikacje zachowań opresyjnych młodych wraz z próbą ich interpretacji czy też pokazanie młodych „poza ławką szkolną”, wskazując na wagary jako zachowanie opozycyjno-buntownicze uczniów.

Pierwszy dzień konferencji zakończył się uroczystą kolacją w „ogrodach jezuickich” uświetnioną koncertem barda Jacka Beszczyńskiego, znanego w toruńskim środowisku animatora, autora muzyki do utworów pisanych 
przez siebie dla dzieci, pierwszego nauczyciela w szkole polskiej na Łotwie, współautora innowacji edukacyjnej wprowadzanej w Przedszkolu Niepublicznym „Słoneczko” w Toruniu, polegającej na nauce czytania metodą teatrzyków muzycznych.

Drugi dzień konferencji został zapoczątkowany sesją plenarną zatytułowaną: Młodzież wobec wartości i kwestii człowieczeństwa. Moderatorami w tej części byli: dr hab. Barbara Grabowska (UŚ), ks. dr Bogdan Stańkowski (AIK). Wystąpienia prelegentów zogniskowane były wokół następującej problematyki: Ryzyka zachowań ryzykownych młodzieży (dr Krzysztof Biel, SJ), Ojczyzna/y młodzież na pograniczu (dr hab. Barbara Grabowska), Młodzi - między potrzebq a odrzuceniem wspólnoty, (prof. UKW dr hab. Ryszarda Cierzniewska), Między tęsknota a pragnieniem, między pustka a otchtania (prof. UMK dr hab. Piotr Petrykowski), Młodzi jako opiekunowie nieformalni osób niesamodzielnych $w$ domach. Wyzwania dla opiekunów rodzinnych, niespokrewnionych $i$ wolontariuszy (prof. UMK dr hab. Piotr Krakowiak).

Referaty plenarne były wprowadzeniem do trzech kolejnych sekcji: $W y$ miary codzienności. Przeciw czemu się buntuja i czego pragna? (moderatorzy: dr hab. Anna Szafrańska, prof. UKW dr hab. Ryszarda Cierzniewska), Religijność i religia w życiu młodzieży. Między wiara a zwatpiniem. (moderatorzy: dr hab. Krystyna Ablewicz, dr Łukasz Kwadrans), Kryzys migracyjny w Europie. Młodzież przeciwko Innego (moderatorzy: prof. dr hab. Liudmyla Khoruzha, dr Ewa Sowa-Bethane). W trakcie obrad trzech sekcji wystąpiło kolejnych 21 osób, prezentujących swoje teksty i prowadzących ożywioną dyskusję.

W debacie odwoływano się do wartości wyznawanych przez młodzież, mówiono o szacunku i tolerancji. Wskazano na istotną rolę religii i jej miejsce w życiu młodego człowieka. Uczestnicy tych sekcji zwrócili uwagę na współczesne zagrożenia w rozwoju młodzieży. Ważnym i aktualnym dzisiaj wyzwaniem jest praca z młodzieżą pochodzącą z innych krajów. Przedstawiono wyniki badań nad postrzeganiem uchodźców z krajów muzułmańskich przez polską młodzież ponadgimnazjalną. Zarówno prelegenci, jak i uczestnicy dyskusji podkreślili rolę szkoły, wychowawców, instytucji państwowych i samorządowych oraz wyższych uczelni w czasie kryzysu migracyjnego w Europie. Prezentowane badania przedstawiały pracę z dziećmi i młodzieżą cudzoziemską prowadzoną w szkołach. Ważnym problemem był stosunek młodzieży do rodzących się ruchów rasistowskich, na przykładzie szkockiego systemu edukacyjnego zaprezentowano metody pracy przeciwdziałające dyskryminacji o podłożu rasistowskim. Uczestnicy konferencji mieli również 
możliwość poznania pracy szkół polskich na Łotwie, przytaczano wyniki badań nad czasem wolnym i zainteresowaniami młodzieży.

Na zakończenie konferencji odbył się panel podsumowujący, podczas którego prof. Maria Marta Urlińska podziękowała wszystkim gościom i uczestnikom dwudniowej debaty w Krakowie. Konferencja przeprowadzona w takiej formie spełniła oczekiwania środowiska akademickiego. Merytoryczna dyskusja przebiegająca w miłej atmosferze sprzyjała nawiązywaniu i zacieśnianiu kontaktów naukowych. Wartością było połączenie sił organizacyjnych kilku ośrodków akademickich, dla których współpraca przy tej konferencji była jednym z wielu przedsięwzięć integrujących środowiska różnych uczelni w kraju i poza jego granicami. Goszczący w Krakowie mieli także zagwarantowane atrakcje. Dzięki uprzejmości dyrektora Muzeum Historycznego Miasta Krakowa uczestnicy Konferencji mieli możliwość obejrzenia stałej wystawy w Muzeum Schindlera, otrzymali także materiały promujące to miejsce. Rada Miasta Krakowa partycypowała w kosztach organizacji tego naukowego forum, za co organizatorzy wielokrotnie dziękowali samorządowcom.

Atutem organizacji tego naukowego wydarzenia było zebranie tak licznego grona, około 80 osób zainteresowanych proponowaną problematyką. Z referatami wystąpiło 55 uczestników przybywających z 20 ośrodków akademickich, w tym 10 osób z pięciu uczelni zagranicznych [Szkocja, Ukraina (Kijów, Żytomierz), Łotwa, Włochy]. Poza Akademią Ignatianum reprezentowane były także: Akademia Pedagogiki Specjalnej im. M. Grzegorzewskiej w Warszawie, Dolnośląska Szkoła Wyższa we Wrocławiu, Olsztyńska Szkoła Wyższa im. J. Rusieckiego, Uniwersytet Mikołaja Kopernika w Toruniu, Uniwersytet im. Adama Mickiewicza w Poznaniu, Uniwersytet im. Jana Kochanowskiego w Kielcach, Uniwersytet Jagielloński, Uniwersytet Pedagogiczny im. KEN w Krakowie, Uniwersytet Papieski Jana Pawła II w Krakowie, Uniwersytet Kazimierza Wielkiego w Bydgoszczy, Uniwersytet w Białymstoku, Uniwersytet Śląski w Katowicach, Uniwersytet Szczeciński, Staropolska Szkoła Wyższa w Kielcach. Na konferencji wystąpienia mieli również praktycy pracujący z młodzieżą.

Obecnie wzbogaceni jesteśmy o nowe doświadczenie, możemy potwierdzić wiele postulatów przedstawionych podczas konferencji. Kondycja młodzieży w epoce późnej nowoczesności stała się niezwykle złożona i niejednoznaczna. Współczesne zmiany społeczne w wymiarze cywilizacyjnym i kulturowym spowodowały, że wiele z klasycznych paradygmatów i pojęć nauk społecznych mogło stracić na swojej aktualności. Należy próbować zatem odnaleźć nowe sposoby konceptualizacji i badania problematyki 
młodzieży, pochylić się nad zagadnieniami kształtowania (się) tożsamości młodzieży w okresie płynnej nowoczesności (w warunkach relatywizmu aksjologicznego). Próbowano zatem w debacie określić rolę podmiotów wychowawczych obecnych w tym procesie, wskazać na szanse i zagrożenia tożsamości ze strony kultury współczesnej czy też przyjrzeć się kryzysom tożsamości. Podjęcie dyskusji w szerokim gronie specjalistów dało możliwość poznania oraz zrozumienia kondycji współczesnej młodzieży. Konferencja służyła nie tylko wymianie myśli, ale przede wszystkim krytycznej analizie i interpretacji najnowszych sposobów ujmowania młodzieży jako podmiotu badań przez pedagogikę, socjologię, psychologię oraz filozofię. Młodzież jest wyzwaniem dla świata dorosłych, ale też jego przyszłością. Bez względu na język, kulturę czy kraj pochodzenia młodzi poszukują nie tylko akceptacji i miłości, ale potrafią też wiele światu ofiarować. Kraków, będąc gospodarzem Światowych Dni Młodzieży, mógł to dostrzec i tego doświadczać w 2016 roku. 